\title{
Communication
}

[Comunicação]

\section{Honey Bees of Santa Catarina, Brazil, have only African mitochondrial DNA}

[Abelhas de Santa Catarina, Brasil, possuem apenas DNA mitocondrial africano]

\author{
M. Lopes-da-Silva ${ }^{1}$, M.A. Dalbó ${ }^{2}$, T.P. Schfaschek ${ }^{2}$, C.J. Arioli ${ }^{2}$, L.C. Stefaniak ${ }^{2}$ \\ ${ }^{1}$ Embrapa Recursos Genéticos e Biotecnologia - Brasília, DF \\ ${ }^{2}$ Estação Experimental de Videira - Videira, SC
}

The accidental release of 26 African honey bee queens (Apis mellifera scutellata) in Brazil in 1957 was the beginning of the Africanization process of honey bees in South America. This was highly impacting on beekeeping across the continent, because, despite being more productive, African honey bees were very aggressive. Many attempts to cross European $\mathrm{x}$ African bees were done in order to obtain less aggressive bees (Michener, 1975). There are slight morphological differences between African and European honeybees. In terms of beekeeping management, however, behavioral differences are more important. Besides stinging, another important difference is hygienic behavior. African honeybees are known to be more effective in eliminating dead larvae and pupae than their European counterparts (Guzman-Novoa et al., 1999). Despite the Africanization, there are still regions with a predominance of European subspecies. For example, in Argentina, there was a significant introduction of European subspecies in highly saturated Africanized honey bee regions in order to slow down the Africanization process. This provided more European gene frequency in North Argentina (Basualdo et al., 2001).

Using the pin-killed brood method (Spivak, Downey, 1998), it was observed a variation in the hygienic behavior of honey bees in Santa Catarina State (SC) (Arioli, personal communication). Within a sample of 16 colonies surveyed, nine were qualified as highly hygienic, four as intermediary and three as not hygienic. These differences and the suspicion of a possible gene flow of European honey bees from
Argentina to Brazil motivated this investigation about the genetic background of honeybees in Santa Catarina (SC).

Approximately 110 samples of workers were collected in 30 points of SC. The distances of these places to the Argentine border varied from 20 to $800 \mathrm{~km}$. The DNA extraction was performed by two methods: the Genomic DNA Extraction Kit ${ }^{\circledR}$ (Real Biotech Corporation) and the CTAB method (Doyle and Doyle, 1987). It was used the cytochrome $\mathrm{B}$ gene amplified by PCR as the genetic marker to distinguish between European and African maternal lines. The combined primers were CytBF: fTATGTACTACCATGAGGACAAATA and CytBR 5'-ATTACACCTCCTAATTTATTAGGAAT-3'

(Hall and Muralidharan, 1989; Crozier et al. 1991).

According to technical specifications, $20 \mu \mathrm{L}$ of the PCR product were incubated with $7 \mu \mathrm{L} \mathrm{Bgl} \mathrm{II}$ $1 \mathrm{U}+$ buffer, at $37^{\circ} \mathrm{C}$ for $2 \mathrm{~h}$ (Crozier et al., 1991). As control and comparison, one pure European honey bee was obtained from a beehive located at Santana do Livramento, Rio Grande do Sul, Brazil, on the border of Uruguay.

The Bgl II enzyme did not cut the PCR product of all the honey bee samples collected in SC and as expected, it cut the product of the European honey bee sample and this indicates that all SC samples have African mtDNA (Fig. 1) A similar result was obtained by Diniz et al. (2003) in Rio Grande do Sul State, near to the border of Uruguay. These results suggested that probably all maternal European lineages of honey bees in Southern Brazil have been eliminated.

Recebido em 1 de dezembro de 2011

Aceito em 12 de janeiro de 2012

E-mail: msilva@cenargen.embrapa.br 


\section{$\begin{array}{lllll}M & 1 & 2 & 3 & 4\end{array}$}

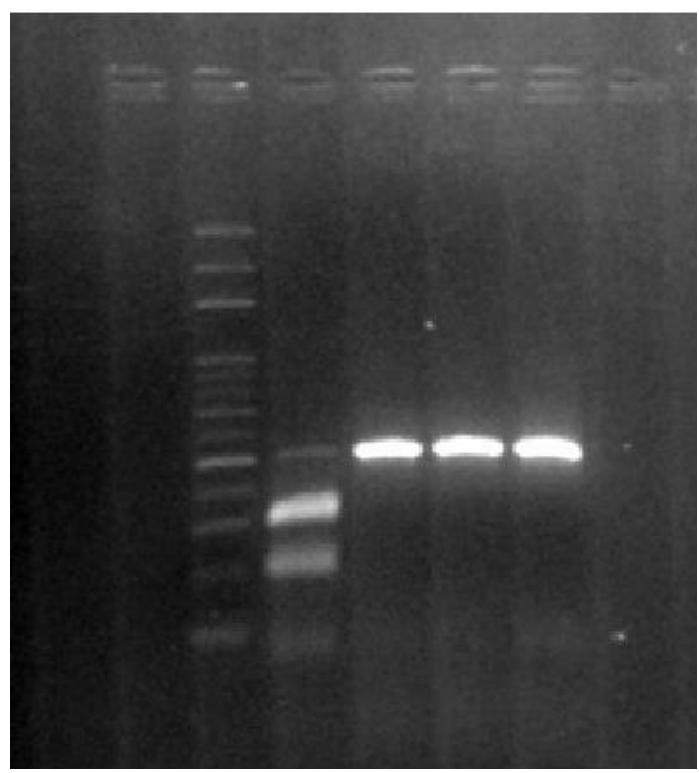

Figure 1. Amplicon of cytochrome B gene fragment from mtDNA of honey bee (Apis mellifera): lane M, 1000 bp Ladder; 1, European honeybee from Santana do Livramento, RS, Brazil; 2-4 Africanized honey bees from Santa Catarina State, Brazil. The PCR products were incubated with restriction enzyme Bg1II.

Natural selection against feral European maternal descendents is a reasonable assumption in tropical climates. Africanized honeybees have reproduction advantages over the European subspecies. This can best explain the predominance of African mtDNA in Neotropical honey bees. In Argentina, Sheppard et al. (1991) found a predominance of African mtDNA in the Northern area and a predominance of European mtDNA from the Buenos Aires province southward. This is an example of the predominance of European genes of honeybees in colder regions. Santa Catarina state is located within approximately the same latitudes as Northern Argentina. The climate of these regions seems to be more adequate for the African subspecies.

Substantial hybridization between these honeybees subspecies was demonstrated and an asymetrical gene flow between African and European derived populations was presumed (Sheppard et al., 1991). Two explanations for the predominance of the African maternal DNA in honeybees of Santa Catarina were suggested. The first, the elimination of European genes is the result of selection (artificial and natural) against lineages derived from crosses between Africanized drones $\mathrm{x}$ European queens. This hypothesis is supported by Hall (1990) and is explained by nuclear-mitochondrial interaction. Another possible reason for European maternal DNA elimination is that non-random mating occurred in an asymmetric way: Africanized drones mated preferentially with Africanized queens in the early stages of African honeybee colonization. This explanation is supported by Sheppard et al. (1991)

The present data combined with other genetic analyses of bees showed that it is impossible to maintain European honey bee maternal lines in the Neotropical region without artificial fecundation. These findings could be extended to other tropical regions of the world where Africanized honeybees are spreading. These results reinforce the argument concerning the ineffectiveness of the introduction of European bee subspecies in Southern Brazil to improve any desirable attributes or add more genetic variability.

Keywords: Hymenoptera, gene flow, maternal lineage

\section{RESUMO}

As diferenças entre a subspécie de abelha africana (Apis mellifera scutellata) e as subspécies europeias (Apis mellifera mellifera $e$ Apis mellifera ligustica) nos quesitos comportamento higiênico $e$ agressividade são marcantes. Diferenças acentuadas no comportamento higiênico entre colônias de abelhas foram relatadas em Santa Catarina, Brasil. Suspeitou-se que essas diferenças fossem devidas a um possível fluxo gênico entre as abelhas africanizadas brasileiras e as abelhas europeias da Argentina. Amostras de abelhas de 30 localidades de Santa Catarina foram analisadas por meio do uso de um marcador PCR-RFLP do DNA mitocondrial específico para identificação da origem da linhagem maternal. Os resultados indicaram ausência de linhagem materna de origem europeia em Santa Catarina. Baseando-se em hipóteses e resultados de trabalhos anteriores, conclui-se que não há fluxo 
gênico entre as populações das diferentes subespécies. $O$ resultado também reforça que a eliminação do DNA maternal europeu é um indicativo de ineficácia de introduções de abelhas de subespécies europeias, no Brasil, com propósitos de melhoramento do atributo agressividade.

Palavras-chave: Himenoptera, fluxo gênico, linhagem materna

\section{ACKNOWLEDGMENTS}

We thank Milton Artuso, a beekeeper from Santa do Livramento, RS, who provided us with European honey bee workers. This research was supported by FAPESC, Fundação de Apoio à Pesquisa de Santa Catarina, nº 19720

\section{REFERENCES}

BASUALDO, M.; PALACIO, M.A.; BEDASCARRASBURE, E.L. Africanized Honeybee Impact in Beekeeping of Argentina. In: INTERNATIONAL APICULTURAL CONGRESS, 37., 2001, Durban, South Africa. Proceedings... Durban, 2001. Apimondia, 2001. Disponível em: <http://www.inta.gov.ar/balcarce/info/documentos/ alter/apic/african.pdf >. Acessado em: 1 dez. 2011.

CROZIER,Y.C.; KOULIANOS, S.; CROZIER, R.H. An improved test for Africanized honeybee mitochondrial DNA. Experientia, v.47, p.968-969, 1991.

DINIZ, N.M.; SOARES, A.E.E.; SHEPPARD, W.E.; DEL LAMA, M.A. Genetic structure of honeybee populations from Southern Brazil and Uruguay. Genet. Mol. Biol., v.26, p.47-52, 2003.
DOYLE J.J.; DOYLE, J.L. Isolation of DNA from fresh plant tissue. Focus, v.12, p.13-15, 1987.

GUZMAN-NOVOA, E.; VANDAME, R.; ARECHAVALETA, M.E. Susceptibility of European and Africanized honey bees (Apis mellifera L.) to Varroa jacobsoni Oud. in Mexico. Apidologie, v.30, p.173-182, 1999.

HALL, H.G.; MURALIDHARAN, K. Evidence from mitochondrial DNA that African honey bees spread as continuous maternal lineages. Nature, v.339, p.211213, 1989.

HALL, H.G. Parental analysis of introgressive hybridization between African and European honeybees using nuclear DNA RFLPs.1990. Genetics, v.125, p.611-621, 1990.

MICHENER, C.D. The Brazilian bee problem. Ann. Rev. Entomol., v.20, p.339-416, 1975.

SHEPPARD, W.S.; RINDERER, T.E.; MAZZOLI, J.A. et al. Gene flow between African and Europeanderived honey bee populations in Argentina. Nature, v.349, p.782-784, 1991.

SPIVAK, M.; DOWNEY, D. Field assays for hygienic behavior in honey bees (Apidae: Hymenoptera). $J$. Econ. Entomol., v.91, p.64-70, 1998. 